\section{Assessment of protein intake during pregnancy using a food frequency questionnaire and the effect on postpartum body weight variation}

\author{
Avaliação do consumo de proteína durante a \\ gestação, com questionário de freqüência e seu \\ efeito na mudança de peso materno no pós-parto
}

\author{
1 Instituto de Nutrição Josué \\ de Castro, Universidade \\ Federal do Rio de Janeiro, \\ Rio de Janeiro, Brasil. \\ 2 Instituto de Medicina \\ Social, Universidade do \\ Estado do Rio de Janeiro, \\ Rio de Janeiro, Brasil. \\ Correspondence \\ M. B. T. Castro \\ Departamento de Nutrição \\ Social e Aplicada, Instituto \\ de Nutrição Josué de Castro, \\ Universidade Federal do Rio \\ de Janeiro. \\ Av. Brigadeiro Trompowsky \\ $s / n$, Bloco J, $2 \underline{o}$ andar, Rio de \\ Janeiro, RJ 21941-590, Brasil. \\ mbtcastro@gmail.com
}

\begin{abstract}
The aim of this study was to investigate the effect of protein intake during pregnancy on postpartum weight variation. This was a prospective cohort study with 421 women interviewed at 15 days (baseline) and 2, 6, and 9 months postpartum. Data on diet were obtained using the food frequency questionnaire, focusing on the second and third trimesters. Protein intake was considered adequate when women consumed $\geq 1.2 \mathrm{~g}$ of protein per $\mathrm{kg}$ body weight, and inadequate when $<1.2 \mathrm{~g} / \mathrm{kg}$. The study adopted the mixed effects model for repeated measurements over time. The results showed a mean postpartum weight loss of $0.409 \mathrm{~kg} /$ month $( \pm 0.12)(p<0.01)$. Women with adequate protein intake during pregnancy lost an additional $0.094 \mathrm{~kg} /$ month $( \pm 0.04)$ during postpartum ( $p=0.03$ ) when compared to women with inadequate intake. The model was adjusted for energy, \% body fat, stature, age, schooling, skin color, and smoking. Recommended protein intake during pregnancy favored postpartum weight reduction.
\end{abstract}

Proteins; Postpartum Period; Body Weight

\author{
Maria Beatriz Trindade de Castro ${ }^{1}$ \\ Gilberto Kac 1 \\ Rosely Sichieri 2
}

\section{Introduction}

In the 1980s and 90s, the World Health Organization (WHO) recommended daily protein intake of $0.91 \mathrm{~g}$ per $\mathrm{kg}$ of body weight $(\mathrm{PR} / \mathrm{kg}) 1$ This daily recommendation represented $10 \%$ to $15 \%$ of the total diet energy. The current protein intake recommendation by the Institute of Medicine 2 is $1.1 \mathrm{PR} / \mathrm{kg}$ for pregnant women. Although there is no solid evidence on variability for recommended protein intake, the Institute of Medicine 2 estimates that it can vary from $10 \%$ to $35 \%$.

Research on protein intake is limited, especially during pregnancy, given the limited knowledge on the long-term consequences of highprotein diets. Pregnancy is almost always considered an exclusion criterion for clinical trials on the theme ${ }^{3,4}$.

In addition, the validity of measuring protein in nutritional epidemiology studies is still a controversial issue 5 . Although numerous validation studies for the food frequency questionnaire (FFQ) have shown that this instrument is adequate for measuring dietary consumption of foods and nutrients 6,7 , including proteins $8,9,10,11$ some authors question its validity 5 . Also, observations during pregnancy include the possibility of overestimating the consumption of healthy foods 12 , variability in consumption at different moments in pregnancy, and some modifications associated with intolerance or eating compul- 
sions resulting from the physiological state of pregnancy 13 .

Evaluation of protein intake in pregnant and lactating women can aim not only at adjusting nutrition to the special requirements of pregnancy and breastfeeding, but also to avoid postpartum weight retention. In a recent study, Castro et al. 14 showed that protein intake greater than or equal to $1.2 \mathrm{PR} / \mathrm{kg}$ favored postpartum weight loss. A clinical trial by Lovelady et al. 15 used $20 \%$ recommended protein in the intervention group to evaluate weight loss in breastfeeding women with overweight. At the end of follow-up, this group had lost more weight and had a diet with $18 \%$ protein, while the control group's diet showed $15 \%$ protein.

Thus, the aim of the current study was to investigate the effect of protein intake during pregnancy on postpartum weight variation. The underlying hypothesis was that high-protein diet favors weight loss.

\section{Material and methods}

\section{Study design and sample}

The current study reports on a prospective cohort of women interviewed at approximately 15 days (baseline) and 2, 6, and 9 months postpartum. Data were collected at the Marcolino Candau Municipal Health Center in the city of Rio de Janeiro, Brazil, from May 1999 to April 2001. The study involved 15 months of recruitment and nine months of follow-up. Further details on the methods and inclusion and exclusion criteria have been published elsewhere 16,17.

Among the 709 women invited to participate in the study, 479 agreed to participate. The following were excluded from the analyses: 47 women younger than 18 years of age and two women with energy intake during pregnancy greater than $6,000 \mathrm{kcal} 18$. Of the total of 430 women $(100 \%)$ included at baseline, 380 (88.4\%), 311 (72.3\%), and $283(65.8 \%)$ were present at 2, 6, and 9 months postpartum, respectively. Previously published analyses showed a random pattern of losses for all the variables except age 19 and beer and liquor consumption 18 . The study was approved by the Institutional Review Board of the Nucleus for Studies in Collective Health (NESC) at the Federal University in Rio de Janeiro (UFRJ). All the study's stages were announced to the participants, who signed a free and informed consent form.

\section{Exposures and outcome}

Information on diet was obtained retrospectively using the FFQ validated by Sichieri 20 , during the first follow-up visit, at 15 days postpartum. The reference period for food intake pertained to the last six months of pregnancy. Intake levels for total energy, protein, and protein foods (eggs, meat, chicken, fish, milk, and beans) were calculated using a program developed in SAS, version 8.2 (SAS Inst., Cary, USA). Table 1 describes protein and protein food inake: (i) in grams; (ii) intake density (nutrients and foods in grams divided by energy intake).

The variable "protein in g per kg body weight per day" (PR/kg) refers to intake during pregnancy as measured at 15 days postpartum, when 421 women (98\%) answered the FFQ. Calculation was based on total protein intake divided by weight measured at baseline [total protein (g) at baseline/weight $(\mathrm{kg})$ at baseline]. The variable $\mathrm{PR} / \mathrm{kg}$ was analyzed as a fixed measurement in time.

Based on the current protein intake recommendation of $1.1 \mathrm{PR} / \mathrm{kg}$ for pregnant women ${ }^{2}$, the study adopted a cutoff point of $1.2 \mathrm{PR} / \mathrm{kg}$. This cutoff was used to distinguish women according to high and low dietary protein levels, as in a previous study ${ }^{14}$. Adequate protein intake was defined as $\geq 1.2 \mathrm{PR} / \mathrm{kg}$. Women with $\mathrm{PR} / \mathrm{kg}$ intake below the cutoff point were defined as having inadequate protein intake.

Weight was measured at all four visits with a digital scale (model PL 150; Filizola São Paulo, Brazil) with a capacity of $150 \mathrm{~kg}$, accurate to $0.1 \mathrm{~kg}$. Participants were weighed barefoot and wearing light clothing. Weight was considered a continuous variable with time-dependent measurement.

\section{Co-variables}

The following information was obtained at baseline: anthropometric [pre-gestational weight $(\mathrm{kg})$, stature $(\mathrm{cm})$, and body fat (\%)]; socio-demographic [family income (in Brazilian Reais), marital status (married/common-law marriage versus single), and skin color (white, brown, or black)]; and lifestyle [smoking (smokers versus non-smokers)]. All the anthropometric measurements were obtained according to the methodology described by Lohman et al. 21 . Stature was measured with $0.1 \mathrm{~cm}$ accuracy using an anthropometer (Harpenden Inc., UK). Body fat percentage was estimated using bioimpedance (BIA 101Q; RJL Inc., USA). Pre-gestational body mass index (BMI) was calculated using the pre-gestational weight reported at the first interview at 15 days postpartum. At two and 
Mean and standard deviation (SD) for protein food intake ( $\mathrm{g}$ ) and intake density ( $\mathrm{g} / \mathrm{kcal}$ ) among 421 women with adequate * versus inadequate ** protein intake per kg body weight (PR/kg) during pregnancy.

\begin{tabular}{|c|c|c|c|c|c|c|}
\hline \multirow[t]{3}{*}{ Variables } & \multicolumn{6}{|c|}{ Protein and protein food intake } \\
\hline & \multicolumn{3}{|c|}{ Gram } & \multicolumn{3}{|c|}{ Density } \\
\hline & $\begin{array}{l}\text { Adequate } \\
\text { intake } \\
\text { Mean (SD) }\end{array}$ & $\begin{array}{l}\text { Inadequate } \\
\text { intake } \\
\text { Mean (SD) }\end{array}$ & $\mathrm{p}$-value $* \star \star$ & $\begin{array}{c}\text { Adequate } \\
\text { intake } \\
\text { Mean (SD) }\end{array}$ & $\begin{array}{l}\text { Inadequate } \\
\text { intake } \\
\text { Mean (SD) }\end{array}$ & $\mathrm{p}$-value *** \\
\hline Energy (kcal) & $3,263(766)$ & $2,263(549)$ & $<0.01$ & $32.6(0.77)$ & $22.6(0.55)$ & $<0.01$ \\
\hline Protein (g) & $101.6(24.2)$ & $64.4(13.4)$ & $<0.01$ & $31.4(4.20)$ & $29.0(4.58)$ & $<0.01$ \\
\hline PR/kg (g/kg) & $1.74(0.50)$ & $0.96(0.17)$ & $<0.01$ & $0.54(0.12)$ & $0.44(0.09)$ & $<0.01$ \\
\hline Eggs (number) & $0.38(0.39)$ & $0.22(0.31)$ & $<0.01$ & $0.12(0.12)$ & $0.10(0.15)$ & 0.16 \\
\hline Chicken (pieces) & $0.85(0.72)$ & $0.46(0.38)$ & $<0.01$ & $0.27(0.22)$ & $0.22(0.22)$ & 0.02 \\
\hline Meat (slices) & $1.01(0.58)$ & $0.65(0.43)$ & $<0.01$ & $0.31(0.16)$ & $0.29(0.20)$ & 0.31 \\
\hline Fish (filets) & $0.30(0.56)$ & $0.16(0.22)$ & $<0.01$ & $0.09(0.10)$ & $0.07(0.11)$ & 0.21 \\
\hline Milk (glasses) & $2.16(1.66)$ & $1.95(1.44)$ & 0.15 & $0.68(0.53)$ & $0.90(0.73)$ & $<0.01$ \\
\hline Beans (servings) & $2.30(1.31)$ & $15.8(0.92)$ & $<0.01$ & $0.74(0.47)$ & $0.74(0.47)$ & 0.95 \\
\hline
\end{tabular}

* Adequate protein intake: $P R / \mathrm{kg} \geq 1.2 \mathrm{~g} / \mathrm{kg}$;

** Inadequate protein intake: PR/kg $<1.2 \mathrm{~g} / \mathrm{kg}$;

$\star \star \star$ Student's t test.

six months follow-up, information was collected on schooling (in years) and parity (primiparous or multiparous), while the variable "total days of predominant breastfeeding" 22 was recorded at all of the visits. The leisure-time physical activity score was estimated at all of the visits, based on the questionnaire developed by Shapiro et al. 23 .

\section{Data analysis}

The study used the mixed effects model for repeated measurements over time 24,25 to assess postpartum weight change as a function of PR/ $\mathrm{kg}$ intake (Figure 1). The analyses were done in the Proc Mixed program, SAS version 8.2. Further details on the modeling process can be found in Castro et al. 14 .

Briefly, the study considered as potential confounding factors the variables from the theoretical causal model, constructed $a$ priori (Figure $2)$, that were associated ( $p \leq 0.20)$ with the outcome variable (weight in $\mathrm{kg}$ ) and the explanatory variable (protein in g). Weight and protein intake in grams were distributed across the various quartiles: income, schooling, pre-gestational BMI, energy, leisure-time physical activity score, stature, percentage body fat, and total days of predominant breastfeeding. The other variables were categorized as follows: age ( $\geq 30,<30$ years), marital status (single versus married or commonlaw marriage), skin color (white, brown, black), parity (primiparous, multiparous), and smoking (smoker versus non-smoker).

In the modeling of repeated measures over time, models A and B are referred to respectively as the unconditional means model and the unconditional growth model. Model C included only the time variable and the predictive variables for weight variation (protein per kg of body weight as a dichotomous variable and its interaction with time). Model D included the variables energy, stature, and percentage body fat at baseline, which were considered confounding factors. As described previously 14 , the age and skin color variables were introduced into model $\mathrm{E}$ because the women with adequate intake were younger and included a higher proportion of brownskinned women $(\mathrm{p}<0.05)$. The variables smoking $(p=0.06)$ and schooling $(p=0.08)$ were added because they displayed a borderline distribution $(\mathrm{p}<0.10)$ at baseline between the groups with adequate and inadequate intake 14 . All these variables were inserted alone and with their interaction with time. Model $\mathrm{F}$ was then adjusted for the variables energy, percentage body fat, and stature at baseline and for age, schooling, smoking, and their interactions with time and skin color. Only the interaction variable skin color*time was excluded. In this final model, except for the variables smoking $(p=0.53)$ and years of schooling $(p=0.17)$, all the others and their respective interactions with time were significantly associated with the outcome $(\mathrm{p}<0.05)$. 


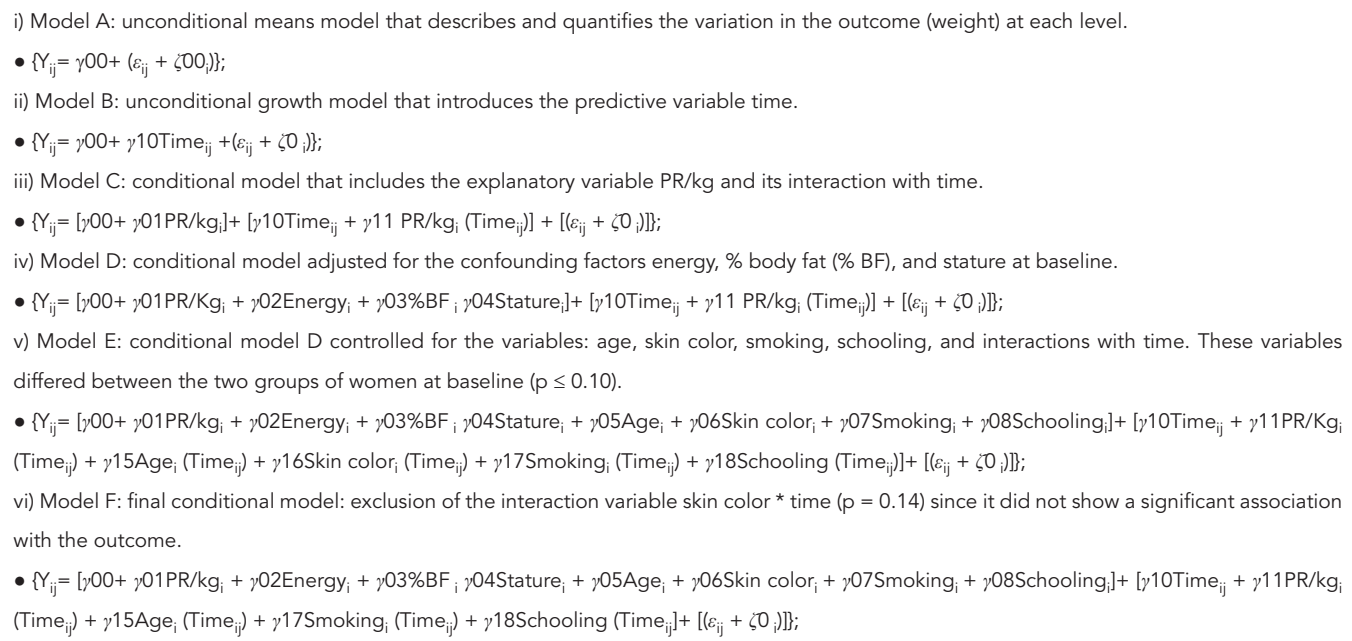

\section{Findings}

Total energy intake was 3,263kcal $( \pm 766 \mathrm{kcal})$ and $2,263 \mathrm{kcal}( \pm 549 \mathrm{kcal})$, respectively, for women with adequate and inadequate $\mathrm{PR} / \mathrm{kg}$ intake, according to the Institute of Medicine recommendations 2 (Table 1). Mean intake was $1.74 \mathrm{PR} / \mathrm{kg}$ $( \pm 0.50)$ among pregnant women with adequate intake and $0.96 \mathrm{PR} / \mathrm{kg}( \pm 0.17)$ for those with inadequate intake.

The findings in Table 1 show that pregnant women with intake $\geq 1.2 \mathrm{PR} / \mathrm{kg}$ showed quantitatively higher intake of all the protein foods analyzed ( $p<0.01)$ except for milk ( $p=0.15)$. As for dietary density, all the pregnant women with adequate intake showed qualitatively higher protein intake for gram weight $(\mathrm{p}<0.01), \mathrm{PR} / \mathrm{kg}$, and chicken $(p=0.02)$. Pregnant women with $P R / k g$ intake lower than the Institute of Medicine recommendations 2 showed a diet with higher milk density $(\mathrm{p}<0.01)$. There was no difference in qualitative intake of beans.

The analyses of repeated measurements over time in model A showed systematic intra and inter-individual weight variation (Table 2). Based on the calculation of the intra-class correlation coefficient $\left(\hat{y}=\sigma_{0}{ }^{2} / \sigma_{0}{ }^{2}+\sigma_{\varepsilon}{ }^{2}\right), 90 \%$ of weight variation was due to differences between women. Inclusion of time as a predictive variable in model B showed that weight variation was linear with time. Using calculation of statistical pseudo $\mathrm{R}_{\varepsilon}{ }^{2}$ \{Pseudo $\mathrm{R}_{\varepsilon}{ }^{2}=\left[\left(\sigma_{\varepsilon}{ }^{2}\right.\right.$ model $\mathrm{A}-\sigma_{\varepsilon}{ }^{2}$ model B)/ $\sigma_{\varepsilon}{ }^{2}$ model A]\}, we estimated that time accounted for $5.4 \%(p<0.0001)$ of weight variation over the course of follow-up. The total proportion of level 2 residual variation explained by the predictive variables was $77.8 \%$ and was calculated by the equation pseudo $\mathrm{R}_{\zeta}{ }^{2}=\left(\sigma_{\zeta}{ }^{2}\right.$ model B $-\sigma_{\zeta}{ }^{2}$ model F) $/ \sigma_{\zeta}^{2}$ model B).

Thus, we observed that the inclusion of second order variables explained most of the weight variation. Model $\mathrm{C}$ shows that the women lost a mean of $0.079( \pm 0.03) \mathrm{kg} /$ month $(\mathrm{p}=0.02)$. This model included the predictive variable $\mathrm{PR} / \mathrm{kg}$ and its interaction with time (Table 2). Based on model $\mathrm{D}$, women with adequate protein intake during pregnancy lost $0.111( \pm 0.04) \mathrm{kg} /$ month more $(\mathrm{p}=0.01)$ than women with inadequate intake. Model F showed a monthly weight loss of $0.409( \pm 0.12) \mathrm{kg}$ among postpartum women with inadequate protein intake in pregnancy $(\mathrm{p}<0.01)$ and that women with adequate intake in pregnancy lost $0.094( \pm 0.04) \mathrm{kg}$ more in the postpartum ( $\mathrm{p}=0.03$ ) as compared to women with inadequate intake. This conditional model was adjusted for the variables energy, percentage body fat, and stature at baseline, and for age, schooling, skin color, and smoking and their interactions with time, except for the interaction variable skin color*time (Table 2 ). 
Figure 2

Hierarchical theoretical model for postpartum weight variation.

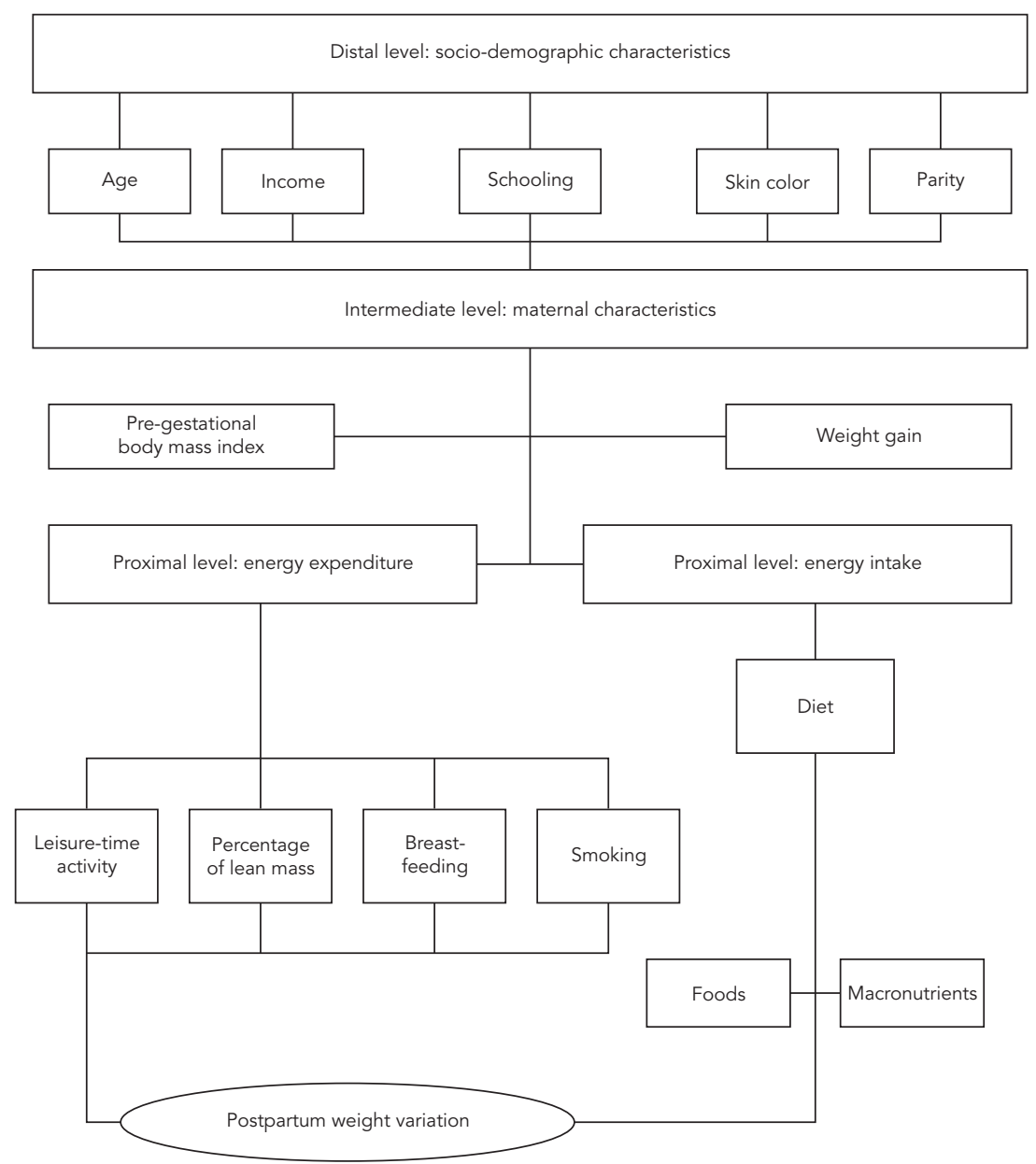

\section{Discussion}

In the current analysis, there was a positive association between postpartum weight loss and protein intake per $\mathrm{kg}$ of body weight during pregnancy. Women that showed $\mathrm{PR} / \mathrm{kg}$ intake greater than or equal to the Institute of Medicine recommendations 2 for pregnancy lost more weight in the postpartum than women with inadequate protein intake. Although the difference was not large, namely around $100 \mathrm{~g}$ / month, this loss can become important over time, both for maintaining and losing weight. Thus, the adoption of a high-protein diet can become a nutritional strategy for postpartum weight loss. Since protein intake is a matter of ordinary food consumption, such a diet is easy to follow and can produce relevant weight reduction over time.

The benefits of a high-protein diet for promoting weight loss have been well documented in the literature $3,4,26,27,28$. However, due to the lack of security in maintaining this type of diet in the long term and its association with the socalled "Western" eating pattern 29,30, pregnant and lactating women are normally excluded from the clinical trials 3,4 . Analysis of usual PR/kg intake was possible due to the reasonable protein intake gradient, although observational studies always have the possibility of residual confounding, even if the analyses are adjusted for known confounding factors. 
Estimated postpartum weight loss in women with adequate * versus inadequate protein intake ** per kg body weight (PR/kg) during pregnancy.

\begin{tabular}{|c|c|c|c|}
\hline \multirow[t]{2}{*}{ Parameter } & \multicolumn{3}{|c|}{ Protein intake during pregnancy } \\
\hline & Model A & Model B & Model C *** \\
\hline \multicolumn{4}{|l|}{ Fixed effects } \\
\hline \multicolumn{4}{|l|}{ Intercept } \\
\hline Weight & $62.2 \# \#( \pm 0.59)$ & $62.8 \# \#( \pm 0.59)$ & $67.8 \# \#( \pm 0.91)$ \\
\hline Adequate intake/Inadequate intake & - & - & $-8.4 \# \#( \pm 1.16)$ \\
\hline \multicolumn{4}{|l|}{ Variation rate } \\
\hline Weighttime & - & $-0.153 \# \#( \pm 0.02)$ & $-0.079 \# \# \#( \pm 0.03)$ \\
\hline Adequate intake*time & - & - & $-0.116 \# \#( \pm 0.04)$ \\
\hline \multicolumn{4}{|l|}{ Components of variation } \\
\hline \multicolumn{4}{|l|}{ Level 1} \\
\hline Intra-individual $\left(\sigma_{\varepsilon}^{2}\right)$ & $5.91 \# \#( \pm 0.27)$ & $5.59 \# \#( \pm 0.23)$ & $5.58 \# \#( \pm 0.25)$ \\
\hline \multicolumn{4}{|l|}{ Level 2} \\
\hline Inter-individual $\left(\sigma_{0}^{2}\right)$ & $147.5 \#( \pm 10.21)$ & $147.8 \#( \pm 10.22)$ & $128.7 \# \#( \pm 9.03)$ \\
\hline \multicolumn{4}{|l|}{ Goodness-of-fit } \\
\hline-2 Res Log Likelihood & $8,337.8$ & $8,289.8$ & $8,099.1$ \\
\hline \multirow[t]{2}{*}{ Akayke Information Criterion } & $8,341.8$ & $8,293.8$ & $8,103.1$ \\
\hline & Model D \# & Model E \# & Model F \# \\
\hline \multicolumn{4}{|l|}{ Fixed effects } \\
\hline \multicolumn{4}{|l|}{ Intercept } \\
\hline Weight & $64.5 \# \#( \pm 0.60)$ & $64.8 \# \#( \pm 1.85)$ & $64.7 \# \#( \pm 1.85)$ \\
\hline Adequate intake/Inadequate intake & $-2.90 \# \#( \pm 0.84)$ & $-2.83 \# \#( \pm 0.86)$ & $-2.84 \# \#( \pm 0.86)$ \\
\hline \multicolumn{4}{|l|}{ Variation rate } \\
\hline Weight*time & $-0.080 \# \#( \pm 0.03)$ & $-0.451 \#( \pm 0.12)$ & $-0.409 \# \#( \pm 0.12)$ \\
\hline Adequate intake*time & $-0.111 \# \#( \pm 0.04)$ & $-0.099 \# \# \#( \pm 0.04)$ & $-0.094 \# \#( \pm 0.04)$ \\
\hline \multicolumn{4}{|l|}{ Components of variation } \\
\hline \multicolumn{4}{|l|}{ Level 1} \\
\hline Intra-individual $\left(\sigma_{\varepsilon}^{2}\right)$ & $5.57( \pm 0.25)$ & $5.45( \pm 0.25)$ & $5.46( \pm 0.25)$ \\
\hline \multicolumn{4}{|l|}{ Level 2} \\
\hline Inter-individual $\left(\sigma_{0}^{2}\right)$ & $35.9( \pm 2.62)$ & $32.8( \pm 2.55)$ & $32.8( \pm 2.55)$ \\
\hline \multicolumn{4}{|l|}{ Goodness-of-fit } \\
\hline -2 Res Log Likelihood & $7,598.8$ & $7,257.1$ & $7,252.7$ \\
\hline Akayke Information Criterion & $7,602.8$ & $7,261.1$ & $7,256.7$ \\
\hline
\end{tabular}

${ }^{*}$ Adequate protein intake: $\mathrm{PR} / \mathrm{kg} \geq 1.2 \mathrm{~g} / \mathrm{kg}$;

** Inadequate protein intake: $\mathrm{PR} / \mathrm{kg}<1.2 \mathrm{~g} / \mathrm{kg}$;

*** Unadjusted model;

\# Adjusted model:

$\# \mathrm{p} \leq 0.01$

$\# \# \mathrm{p} \leq 0.05$

Note: Models A, B, C, D, E, and F contain random intercepts. Models A and B are referred to respectively as unconditional means model and unconditional growth model. Model C included the predictive variable PR/kg. Model D was adjusted for the variables energy, \% body fat, and stature at baseline. Model E included the variables age, skin color, smoking, and schooling and interactions with time. Model F excluded the interaction variable skin color*time. The continuous variables in Models D, E, and F were centered to the mean (population mean value minus the individual value for the variable). We chose the unstructured method that considers the inter-measurement correlation between occasions.

Importantly, the FFQ uses a predefined list of foods, and it is thus impossible to rule out the presence of other protein food sources in pregnant women's diet. The cutoff point of $1.2 \mathrm{~g}$ protein per $\mathrm{kg}$ body weight to classify pregnant women's intake as adequate or inadequate aimed to distinguish women according to dietary protein levels.

Few studies have verified the validity of using FFQ to assess food intake during pregnancy 31,32,33,34. In Brazil, only one study was found on validation of the FFQ in pregnant women 11 . The 
authors discuss the fact that although the FFQ overestimated energy and nutrient intake, the same did not occur with protein intake among pregnant women in the city of Bento Gonçalves, Rio Grande do Sul State, Brazil. Studies outside of Brazil have also concluded that the FFQ is a valid, adequately reproducible instrument for assessing intake in pregnant women, for example Fawzi et al. 32 in the United States and Erkkola et al. 31 and Brantsaeter et al. ${ }^{34}$, respectively, on Finnish and Norwegian pregnant women.

One of the difficulties in conducting validation studies in pregnant women consists of the possible variability in intake at different moments in pregnancy and the changes associated with food intolerance or compulsions 13. In Brazil, Souza \& Sichieri 35 and Barros et al. 36 used simplified versions of the FFQ 20 used in the current study to measure food intake in pregnant women and obtained associations that were similar to those reported elsewhere in the literature.

Brown et al. 37 , in a study of 56 American women enrolled in the Diana Project on variation in food intake from the pre-gestational period through pregnancy, detected changes in the intake of energy and certain nutrients, as observed in a preliminary analysis of the data under discussion ${ }^{18}$. The authors noted a quantitative decrease in food intake and a qualitative variation in diet from pregnancy to postpartum. The women that most limited their intake from one period to the other showed an increase in dietary protein density.
As expected, women reported higher food intake in pregnancy as compared to postpartum 18, but overestimation of intake cannot be ruled out especially for commonly recommended foods like fruit, meat, milk, and dairy products. Verbeke \& Bourdeaudhuij 12 observed that pregnant women tend to overestimate their consumption of fruit, red meat, milk, and dairy desserts when compared to non-pregnant women.

Other studies have observed the positive effects of high-protein diet on body composition. In a clinical trial by Westerterp-Plantenga et al. 38 on excess weight $(n=148)$, diets with $20 \%$ protein provided greater satiety, and the weight regain rate was $50 \%$ lower in the group that received additional protein. Treyzon et al. 39 observed that individuals assigned to the high-protein diet group lost more body fat than those in the control group.

A negative correlation was observed between weight retention and high-protein diet, since women that reported high protein intake were leaner at baseline and at nine months of followup. Although it was not possible to assess the exact mechanisms involved in postpartum weight variation, the results suggest the need to monitor protein intake during pregnancy as an additional factor to be considered in the evaluation of nutritional status during this period. The current study corroborated the hypothesis that recommended protein intake in pregnancy favors postpartum weight reduction.

\section{Resumo}

Investigar o efeito do consumo de proteína durante a gestação na variação de peso no pós-parto. Trata-se de coorte prospectiva com 421 mulheres entrevistadas aos 15 dias (linha de base), 2, 6 e 9 meses pós-parto. Os dados dietéticos foram obtidos pelo emprego do questionário de freqüência de consumo alimentar com referência para o segundo e terceiro trimestres gestacionais. O consumo protéico foi considerado adequado entre as mulheres com ingestão $\geq 1,2 \mathrm{~g} / \mathrm{kg}$, e inadequado $<1,2 \mathrm{~g} / \mathrm{kg}$. Empregou-se o modelo de efeitos mistos para medidas repetidas no tempo. Os resultados mostraram uma perda de peso média de 0,409kg/mês $( \pm 0,12)$ no pós-parto $(p<0,01)$. Mulheres com consumo adequado de proteína na gestação perderam adicionalmente $0,094 \mathrm{~kg} / \mathrm{mês}( \pm 0,04)$ no pós-parto $(p=0,03)$ do que as mulheres com consumo inadequado. $O$ modelo fo $i$ ajustado para energia, percentual de gordura corporal, estatura, idade, escolaridade, cor da pele e tabagismo. O consumo recomendado de proteína na gestação favoreceu a redução de peso no pós-parto.

Proteína; Período Pós-Parto; Peso Corporal 


\section{Contributors}

M. B. T. Castro and R. Sichieri participated in the study conceptualization, data analysis and interpretation, and preparation and revision of all versions of the manuscript. G. Kac participated in all stages of the resear$\mathrm{ch}$, from planning to the final revision of the article.

\section{Acknowledgments}

M. B. T. Castro received a PhD scholarship from the Graduate Studies Coordinating Board (CAPES). G. Kac and R. Sichieri received research grants from the National Research Council (CNPq). The original research project was funded by the José Bonifácio University Foundation (FUJB) of the Federal University in Rio de Janeiro (UFRJ) and the Rio de Janeiro State Research Foundation (FAPERJ).

\section{References}

1. Food and Agriculture Organization/World Health Organization/United Nations University. Energy and protein requirements. Geneva: World Health Organization; 1985.

2. Institute of Medicine. Dietary reference intakes for energy, carbohydrate, fiber, fat, fatty acids, cholesterol, protein, and amino acids (macronutrients). Washington DC: National Academy Press; 2005.

3. Westman EC, Yancy WS, Edman JS, Tomlin KF, Perkins CE. Effect of 6 month adherence to a very low carbohydrate diet program. Am J Med 2002; 113:30-6.

4. Foster GD, Wyatt HR, Hill JO, McGuckin BG, Brill C, Mohammed BS, et al. A randomized trial of a lowcarbohydrate diet for obesity. N Engl J Med 2003; 348:2082-90.

5. Kipnis V, Midthune D, Freedman L, Bingham S, Day NE, Riboli E, et al. Bias in dietary-report instruments and its implications for nutritional epidemiology. Public Health Nutr 2002; 5:915-23.

6. Willett WC, Sampson L, Stampfer MJ, Rosner B, Bain C, Witschi J, et al. Reproducibility and validity of a semi-quantitative food frequency questionnaire. Am J Epidemiol 1985; 122:51-65.

7. Mayer-Davis EJ, Vitolins MZ, Carmichael SL, Hemphill S, Tsaroucha G, Rushing J, et al. Validity and reproducibility of a food frequency interview in a multi-cultural epidemiologic study. Ann Epidemiol 1999; 9:314-24.
8. Forsythe HE, Gage B. Use of multicultural food-frequency questionnaire with pregnant and lactating women. Am J Clin Nutr 1994; 59 Suppl:203S-6S.

9. Katsouyanni K, Rimm EB, Gnardellis C, Trichopoulos D, Polychronopoulos E, Trichopoulou A. Reproducibility and relative validity of an extensive semi-quantitative food frequency questionnaire using dietary records and biochemical markers among Greek schoolteachers. Int J Epidemiol 1997; 26 Suppl 1:S118-27.

10. Morin P, Herrmann F, Ammann P, Uebelhart B, Rizzoli R. A rapid self-administered food frequency questionnaire for the evaluation of dietary protein intake. Clin Nutr 2005; 24:768-74.

11. Giacomello A, Schmidt MI, Nunes MAA, Duncan BB, Soares RM, Manzolli P, et al. Validação relativa do questionário de freqüência alimentar em gestantes usuárias de serviços do Sistema Único de Saúde em dois municípios no Rio Grande do Sul, Brasil. Rev Bras Saúde Matern Infant 2008; 8: 445-54.

12. Verbeke W, Bourdeaudhuij I. Dietary behavior of pregnant versus non-pregnant women. Appetite 2007; 48:78-86.

13. Meltzer HM, Brantsaeter AL, Ydersbond TA, Alexander J, Haugen M. Methodological challenges when monitoring the diet of pregnant women in a large study: experiences from the Norwegian Mother and Child Cohort Study (MoBa). Matern Child Nutr 2008; 4:14-27. 
14. Castro MBT, Kac G, Leon AP, Sichieri R. High-protein diet promotes a moderate postpartum weight loss in a prospective cohort of Brazilian women. Nutrition 2009, 25:1120-8.

15. Lovelady CA, Stephenson KG, Kuppler KM, Williams JP. The effects of dieting on food and nutrient intake of lactating women. J Am Diet Assoc 2006; 106:908-12.

16. Kac G, Benício MHD’A, Valente JG, VelásquezMeléndez G. Postpartum weight retention among women in Rio de Janeiro: a follow-up study. Cad Saúde Pública 2003; 19 Suppl 1:S149-61.

17. Kac G, Benício MHD’A, Velásquez-Meléndez G, Valente JG. Nine months postpartum weight retention predictors for Brazilian women. Public Health Nutr 2004; 75:621-8.

18. Castro MBT, Kac G, Sichieri R. Padrão de consumo alimentar em mulheres no pós-parto atendidas em um centro municipal de saúde do Rio de Janeiro, Brasil. Cad Saúde Pública 2006; 22:1159-70.

19. Kac G, Benício MHD’A, Velásquez-Meléndez G, Valente JG, Struchiner CJ. Breastfeeding and postpartum weight retention in a cohort of Brazilian women. Am J Clin Nutr 2004; 79:487-93.

20. Sichieri R. Epidemiologia da obesidade. Rio de Janeiro: EdUERJ; 1998.

21. Lohman TG, Roche AF, Martorell R. Anthropometric standardization reference manual. Champaign: Human Kinetics Books; 1988.

22. World Health Organization/United Nations Children's Fund. Indicators for assessing health facility practices that affect breastfeeding. Report of the Joint WHO/UNICEF Informal Interagency Meeting. Geneva: World Health Organization/United Nations Children's Fund; 1992.

23. Shapiro S, Weinblat E, Frank CW, Sager RV. The H.I.P study of incidence and prognosis of coronary heart disease. J Chron Dis 1965; 18:527-8.

24. Singer JD, Wilett JB. Applied longitudinal analysis: modeling change and event occurrence. Oxford: Oxford University Press; 2003.

25. Spyrides MHC, Struchiner CJ, Barbosa MTS, Kac G. Amamentação e crescimento infantil: um estudo longitudinal em crianças do Rio de Janeiro, Brasil, 1999/2001. Cad Saúde Pública 2005; 21:756-66.

26. Farnsworth E, Luscombe ND, Noakes M, Wittert G, Argyiou E, Clifton PM. Effect of a high-protein, energy-restricted diet on body composition, glycemic control, and lipid concentrations in overweight and obese hyperinsulinemic men and women. Am J Clin Nutr 2003; 78:31-9.
27. Hu FB. Protein, body weight, and cardiovascular health. Am J Clin Nutr 2005; 82(1 Suppl):242S-7S.

28. van Meijl LEC, Vrolix R, Mensink RP. Dairy product consumption and the metabolic syndrome. Nutr Res Rev 2008; 21:148-57.

29. Sichieri R. Dietary patterns and their associations with obesity in the Brazilian city of Rio de Janeiro. Obes Res 2002; 10:42-9.

30. Popkin BM. Global nutrition dynamics: the world is shifting rapidly toward a diet linked with noncommunicable diseases. Am J Clin Nutr 2006; 84:289-98.

31. Erkkola M, Karppinen M, Javanainen J, Räsänen L, Knip M, Virtanen SM. Validity and reproducibility of food frequency questionnaire for pregnant Finnish women. Am J Epidemiol 2001; 154:466-76.

32. Fawzi WW, Rifas-Shiman SL, Rich-Edwards JW, Willett WC, Gillman MW. Calibration of a semiquantitative food frequency questionnaire in early pregnancy. Ann Epidemiol 2004; 14:754-62.

33. Mikkelsen TB, Osler M, Olsen SF. Validity of protein, retinol, folic acid and n-3 fatty acid intakes estimated from the food-frequency questionnaire used in the Danish National Birth Cohort. Public Health Nutr 2006; 9:771-8.

34. Brantsaeter AL, Haugen M, Alexander J, Meltzer HM. Validity of a new food frequency questionnaire for pregnant women in the Norwegian Mother and Child Cohort Study (MoBa). Matern Child Nutr 2008; 4:28-43.

35. Souza RAG, Sichieri R. Consumo de cafeína e de alimentos-fonte de cafeína e prematuridade: um estudo caso-controle. Cad Saúde Pública 2005; 21:1919-28.

36. Barros DC, Pereira RA, Gama SGN, Leal MC. O consumo alimentar de gestantes adolescentes no Município do Rio de Janeiro. Cad Saúde Pública 2004; 20 Suppl 1:S121-9.

37. Brown JE, Buzzard M, Jacobs DR, Hannan PJ, Kushi LH, Barosso GM, et al. A food frequency questionnaire can detect pregnancy-related changes in diet. J Am Diet Assoc 1996; 96:262-6.

38. Westerterp-Plantenga MS, Lejeune MPGM, Nijs I, van Ooijen M, Kovacs EMR. High protein intake sustains weight maintenance after body weight loss in humans. Int J Obes 2004; 28:57-64.

39. Treyzon L, Chen S, Hong K, Yan E, Carpenter CL, Thames G, et al. A controlled trial of protein enrichment of meal replacements for weight reduction with retention of lean body mass. Nutr J 2008; 7:23.

Submitted on 10/Aug/2009

Final version resubmitted on 13/Nov/2009

Approved on 07/Jan/2010 